\section{ON THE USE OF REFRIGERATION IN}

\section{THE PRESERVATION OF FOODS.*}

BY WM. HANNA, M.A., M.D., D.P.H., Assistant Medical Officer of Health, Port of Liverpool.

THE preservation of foods is a subject of intense interest and importance to health authorities; it is a subject, however, which covers a wide range, and it will be best to confine attention to that process which is probably the most recent, the least objectionable, and the one which will become in the near future of vast magnitude.

During the past twenty years the population of the United Kingdom has increased by about Ig per cent., and owing to this fact, coupled with the stationary condition as regards production of our home-grown beef and mutton, the demand for imported supplies has become greater every year.

Endeavours are now being made all over the world to increase the production of food supplies, and to bring them in a preserved condition to our very door.

Some years ago the United States was the largest supplier of meat (in beef and live stock) to this country, and the imports equalled 23 I,595 tons; last year only about 800 quarters of beef and Io, ooo head of cattle arrived, representing 3,3 I 6 tons.

The population of the United States has increased enormously, and in addition there has been a decrease in the production of cattle. As a result, at the present time the position is that the United States requires all this meat and more for its own home consumption, the States has now become a free importer of Australian and South American meats, receiving shipments in both western and eastern ports ; no less than $6,62 \mathrm{I}$ tons of this meat have been re-exported from England, mostly through Liverpool. The United States has, therefore, almost ceased to be a source of supply of beef and mutton to the British market.

Another factor to be considered in connection with this general increasing demand for food is the growth of this trade as regards continental countries; many of these, through agrarian interests, still place many obstacles, such as high Customs' charges or special methods of importation, on the introduction of these products across their frontiers. Others, like Italy and Switzerland, are gradually appreciating the value of such imports, so that as time goes on we shall, no doubt, see many

* Read before a Meeting of the Society of Medical officers of Healuh on Friday, thth February, 19I4. of the large continental countries drawing on our sources of supply, and of necessity other areas must be opened up. The total imports of chilled and frozen beef, mutton, and lamb into the United Kingdom during the past three years is as follows:-628,233 tons in I. II $1,642,537$ tons in I9I2, and 720,66 I tons in I9 3 , reaching a value in I9r 3 of $£ 26,662,896$.

Methods of ReFrigeration.

The methods of refrigeration depend chiefly on the scientific fact that expanding air or vapourising substances, such as sulphurous acid, carbonic acid, or ammonia, in assuming the gaseous form abstract heat from the atmosphere or other bodies in the neighbourhood.

Three processes are in use in the production of cold :-

I. Direct expansion of the refrigerating agent.

2. Brine circulation.

3. Cold-air blast.

In the direct expansion method the evaporating agent is carried in pipes through the storage-chambers, and there is a direct transference of heat from the atmosphere of these chambers to the refrigerating agent.

It is a good method, but is not suitable for refrigeration in general.

With brine circulation the refrigerating agent does not enter the cool chamber, but is used to reduce the temperature of a brine solution which circulates through pipes in the storagechambers. The temperature in the different rooms is obtained by regulating the quantity of brine passing through the pipes, and it has been found that, in order to keep an even temperature, it is better to circulate a large quantity of brine at a temperature just below that required than to circulate small quantities much below that temperature. This method is in use for the carriage of chilled or frozen meat on board ship.

In the cold-air blosst system there are no pipes in the chill-rooms; the air is cooled by being blown over cooled pipes arranged in the form of a battery through which the refrigerating agent is circulating, or through a shower-bath of cold brine. This cooled air is circulated through the chill-room by electric fans, and is used over and over again. This method is only applied to the carriage of frozen cargoes, but may be used in combination with brine circulation in cold stores.

Any moisture in the air is frozen out on the battery coils; in this way the air is rendered dry, and is liable to absorb moisture from the goods in the store, with the result that the 
food products may shrivel and lose weight. The temperature in the room must be steady; it must not be too high or too low, but well chosen in regard to the articles to be preserved. Besides the lowering of the temperature of chill-rooms and holds, two other very important factors are required for successful preservation of foods, namely, the hygrometric conditions and purity of the air.

The air must not be too dry, and the amount of humidity most favourable varies with the substance preserved. If air saturated with moisture be taken as 100 , the following are the comparative figures for various substances:Cheese, 85 ; eggs, 80 ; meat (chilled and frozen), $70-80$; poultry, 6o; and dry fruit, 5o. Unless adequate ventilation be provided the air becomes musty, and natural ventilation is frequently insufficient. Artificial methcds are, therefore, required to carry off excess quantities of water vapour and to introduce cold and dry air. In connection with the chilling of meat a method has been in use for some years by which cold, dry air with formalin vapour is circulated in the holds of the vessel, and is supposed also to prevent the growth of moulds on the meat when the voyage is extended.

The process consists in the use of formaldehyde vapour ( $I O \mathrm{O} z$. of formalin to $\mathrm{I}, \mathrm{OOO} \mathrm{cb}$. ft.) to sterilise the holds; this is swept out by a current of pure, dry air; the meat is then placed in position, and formaldehyde gas again circulated in the holds, which are reduced in temperature to $0^{\circ} \mathrm{C}$. During the voyage cold air dried over $\mathrm{H}_{2} \mathrm{SO}_{4}$ and calcium chloride is circulated for half an hour every day. This meat arrives in very good condition, but has been found to contain small quantities of formalin. A recent sample showed 8 parts per million to a depth of $\frac{1}{4}$ inch, and $\frac{1}{2}$ part per million deeper in the muscle. It is a wellknown fact that formalin may retard digestion even in minute quantities.

\section{Preservation of Different Foods.}

The different modes of preserving food-stuffs by refrigeration vary according to the substance to be preserved, and this has required a great deal of experimentation and experience to bring about perfection.

Fresh Meats are carried by two methods, viz., hard frozen meat and chilled meat.

The hard freezing of meat, at probably $-9^{\circ}$ to $-\mathrm{r} 2^{\circ} \mathrm{C}$. is indispensable for long voyages such as that from Australia, New Zealand or Argentine, and the great bulk of meat products is imported in this condition. These goods have to be thawed out before they can be utilised.

The chilling of meat is carried out by the carcases after slaughter being exposed to a strong current of air, which cools the meat and dries the surface quickly; the meat is then passed through cooling-rooms, which gradually bring it to the temperature required, namely, $2^{\circ} \mathrm{C}$. or $0^{\circ} \mathrm{C}$. Finally it is stored at $-2^{\circ} \mathrm{C}$., and can be kept at this temperature for a period of $2 \mathbf{r}$ to 28 days. This chilled beef arrives in this country in a condition ready for consumption. Of these two processes the frozen method is the better one as regards preservation, although it somewhat damages the cellular and fibrous structure of the meat unless special care be taken in defrosting; and, although it has been said that frozen meat when thawed out more readily decomposes, yet experience shows that frozen meat will keep with proper care as well as freshlykilled meat after being taken from the refrigerator even in high temperature.

Chilled beef retains the characters of fresh beef more closely than frozen meat, but the chilling process requires great care, and the transport needs constant supervision.

In the preservation of fish, freezing is superior to chilling; nevertheless, care is required in the use of refrigeration for fish. Some fish, e.g., salmon, are covered with a thin layer of water and frozen; this has the object of preventing evaporation. Large quantities of frozen salmon are imported from Canada, Russia, etc. When fatty fish like salmon and eels are brought at low temperatures the fat cells may burst and the oil find its way through the tissues or through the skin, and finally the flesh may become rancid and rank. Freezing is also superior to chilling for fish because of the delicate nature of the flesh being subject more readily to a process of autolysis.

Cheese is frequently preserved in chill rooms, but the cold has the effect of retarding the ripening.

The preservation of milk by pasteurisation requires a rapid reduction of temperature following this process, so as to preserve the milk and retard development of organisms.

It has been shown that milk kept at $-\mathrm{I}^{\circ} 6^{\circ} \mathrm{C}$., which is a temperature sufficient to cause ice crystals to form in milk, shows a gradual, though slow, development of bacteria.

Wiley and other American workers have even shown that at $-I 7^{\circ} \mathrm{C}$. there has been a certain amount of growth of organisms in frozen cream. 
The cold storage of eggs in transport or in store is now an important industry; they are packed in thin wooden boxes, with individual cells made of cardboard for each egg. The question of temperature is important for this product. Moderature temperatures, e.g., $4^{\circ} \mathrm{C}$., are employed, and it is necessary to use this temperature for periods not over four months, for the yolk rises and sticks to the shell and will cause premature decay or "spotting" of the egg. The boxes must therefore be turned every week to prevent the light yolk which rises to the highest point adhering to the shell. If the temperature be lower, e.g., $0^{\circ} \mathrm{C}$., the yolk and albumen are more solid; fresh eggs freeze at $-6^{\circ} \mathrm{C}$. The humidity of the chamber is very important, and should be about $75-80$ per cent.; too high a humidity favours the growth and entrance of moulds into the egg and too low a humidity facilitates the evaporation of the contents. Once mould attacks eggs it means "musty" eggs, and a very considerable loss commercially.

When eggs are carried in bulk, i.e., without the shells and mixed, from far-off lands, such as China, it is necessary to test the cans individually with a trier. This instrument is passed in and some of the frozen egg substance is withdrawn and tested for mustiness by the sense of smell. This operation requires such mental concentration that any noise such as made by a hammer or the rumbling of carts in the neighbourhood will seriously interfere with the testing operation.

Game and poultry bear freezing well, and large quantities are imported regularly from Australia, New Zealand, China, Canada and other parts; rabbits and hares bear a temperature of $-9^{\circ} \mathrm{C}$. without damage for a long time, but in case of poultry and other birds, where the texture of the flesh is soft and fine, care is needed in the temperature of refrigeration. The methods of transportation and packing of poultry and game to the cooling factories after they are killed are important; the transportation may be slow and hence decomposition may be present before reaching the cold store.

Certain kinds of fresh fruit have for some years been carried to this and other countries in a chilled state. The factors best adapted for the proper refrigeration of fruit are those at which the vital phenomena of respiration and other chemical and vital activities are slowed, and therefore dark rooms and an excess of $\mathrm{CO}_{2}$ in the atmosphere are advantageous; a low and constant temperature is needed, such as $I^{\circ}$ or $2^{\circ} \mathrm{C}$. for ripe and almost ripe fruit, such as peaches, plums, etc.; and $2^{\circ}$ to $6^{\circ} \mathrm{C}$. for fruits such as apples and pears; sudden chilling and thawing injure the fruit. The humidity ought to be right, for if the store atmosphere be too dry evaporation occurs, and if too humid moulds rapidly develop.

Apples and pears can be kept for 8-10 months, but such fruits as peaches and plums only about 8 weeks. Wrappers are useful; it will often be found that well packed apples will show a dead or decayed sample surrounded by perfect ones, and no contamination will occur for months. The explanation of this is that the natural waxy material on the sound skin protects them from infection.

The damage which occurs during transit or storage was at one time very heavy, and was chiefly due to improper handling and packing. In the case of oranges and lemons, formerly 20-30 per cent. were rendered unsound by decay, but by improved handling and packing at the fruit farms and during transit, to prevent mechanical injuries, so that mould spores do not get an opportunity of entering the fruit, a better product is now entering this country.

The banana trade from the West Indies (Jamaica) has developed rapidly of late years; this is due to the use of cold air in the transport, and ships enter the Liverpool docks weekly. The bunches of green fruit are carried in holds chilled by air currents which have passed over brine coils. The temperature is usually $12^{\circ}$ to $13^{\circ} \mathrm{C}$., and after landing the fruit has to be ripened for market by dry heat, which is never over $2 \mathrm{I}^{\circ} \mathrm{C}$. This is done in the case of Jamaica bananas in maturing rooms; the bunches are suspended from the ceiling. The heat is obtained from the use of Bunsen burners or electric radiators, and the fruit matures in about a week. This is the only area from which chilled bananas are obtained.

Physical Effects of Freezing.

It has been shown by Pennington, Wiley and others, in researches carried on under the U.S, Department of Agriculture, that poultry placed under refrigeration at $-10^{\circ} \mathrm{C}$. will show little change to the eye during the first few months; when this period is prolonged, however, to 8-10 months the muscle tissue becomes darkened, the colour of the fat deepens, and the skin begins to dry and shrivel; if the birds are disposed of promptly the effects of refrigeration may not be so noticeable. The desiccation of skin and muscles after prolonged refrigeration may be improved by soaking in water, but it 
does not restore freshness. The freezing of muscle has the effect of pushing apart the fibres, and the sarcolemma may become slightly ruptured, allowing a certain amount of exudate to escape, but freezing of animal tissues does not necessarily result in rupture of the cellular elements. The question of the effect of freezing on the meat tissues at different temperatures is yet little understood, but Richardson, of the American Chemical Society, has contributed some information of importance. His observations may be summarised as follows :- That at the ordinary temperature in refrigerators containing meat $\left(-9^{\circ}\right.$ to $-12^{\circ} \mathrm{C}$.) the frozen beef juice consists of hard ice crystals and a relatively small amount of a gummy viscous concentrated solution of more soluble constituents of the juice. At a still lower temperature, e.g., $-30^{\circ} \mathrm{C}$., the whole mass will solidify. The water freezes outside the muscle fibres, leaving them more or less isolated and distorted, and this increases as the temperature falls. When thawing takes place, the lower the temperature at which the meat was held the more difficult for the meat fibres to reabsorb the water. If the process of thawing be conducted slowly and evenly it will be found that the tissue elements will more nearly resume their original appearance.

The effect of refrigeration on the nutrient value of foods, and consequently on health, is of importance.

It has become a thing of the past for any but the epicure to scoff at refrigeration as a method of food preservation, and there is no proof that refrigeration causes any serious change either in taste or nutrient value in foods which have been properly defrosted after refrigeration; but this can only be considered as accurate for periods up to about six months or a year; after this, desiccation gradually takes place and the loss of nitrogen becomes apparent, and it must be concluded that some loss of nutrient value occurs.

There is no doubt that the maturation or autolysis which meat undergoes when hung for a short time at a cool temperature still continues when the temperature is lowered to even freezing point. Müller has shown that at $2^{\circ}$ to $3^{\circ} \mathrm{C}$, although putrefaction is stopped, maturation continues, and this is due in all probability to the activity of unknown enzymes. This is a subject worthy of further investigation.

\section{Unsound Conditions Affecting}

Refrigerated Produce.

A careful supervision of the conditions of imported foods entering this country is required under the Foreign Meat and Unsound Food Regulations, and it will be of interest to note some of the more important conditions of unsoundness which arise from time to time and which necessitate treatment by the Officers of the Port Sanitary and other Authorities.

These conditions as regards unsoundness may be divided into two classes:- -

r. Those which usually occur or arise in the foods before refrigeration.

2. Those which arise during refrigeration on shipboard or elsewhere.

Under the first category we must place those diseases which arise during life, such as tuberculosis, the presence of parasites, both animal and vegetable, and other diseased conditions.

At the outset it may be definitely stated that, owing to the very good inspection carried out at the present time in nearly all the countries of export, the proportion of diseased meat present in the vast importations of all kinds which reach this country is very small. Certainly we have had tuberculosis in animals from nearly all exporting countries, but as a rule they were lesions, which, in many cases, with the best inspection might have been over-looked.

There were 59,000 carcases of pigs from China imported during the years I9IO-II-I2 into Liverpool, and only $54 \mathrm{I}$ were found to be affected with tuberculosis, after a very complete examination of every carcase. Another disease which we frequently come across is actinomycosis.

It is some years since the food inspectors at the Port of Liverpool first noticed the presence of actinomycotic nodules in frozen udders imported from United States and Canada; those udders are used as a food product in many of the mining and factory districts of the North of England. This disease, as is well known, is not infrequent in the udders of cattle, and especially in sows, in this country; the fungus in the straw with which the animals are bedded gains an entrance through an abrasion, owing to a scratch, bite or other injury during suckling. Many cases have been seen at the Liverpool Abattoirs amongst Irish sows.

Frozen tongues from the Argentine have also been seriously afrected with actinomycosis. The Liverpool port inspectors discovered the presence of this fungus in frozen tongues early last year and the Local Government Board were at once notified, so that other centres of 
importation might be duly warned. Our united efforts have caused more care to be latterly exercised in the South American inspection; some diseased tongues in the early stages are, however, still imported.

Parasitic diseases are more frequently found. The Australian worm nodules which mainly affect the briskets and knee joint of cattle has proved very troublesome and caused large quantities of frozen meat to be held up at out ports for inspection.

The Australian Government has now ordered the affected parts to be removed and prohibits the exportation of diseased portions. In spite of this regulation we occasionally come across these nodules.

The cause of this infection is a small filarialike worm (Onchererca) which becomes encapsulated in the tissues; the transmitting agent has not been traced. It was suggested to me some time ago that possibly the transmission might be due to a tick in the long grass, for we know that Texas fever is transmitted by ticks in this manner; the position of the lesions, viz., the neighbourhood of the brisket and the knee joint, would also lend some support to this theory. Our experience at Liverpool is that bull beef is rarely affected with nodules because the biting agent does not attack the bulls owing to their strong odour.

According to Dr. MacFadden and Dr. Leiper there is no evidence of vitality in the worm or its embryo in any of the beef reaching this country.

The so-called "Measles" of beef due to larval taenia has not so far been found in imported beef, but we know that it is found to about I per cent. in United States cattle.

The allied parasite in pork has been found in eight pigs out of the 59,000 imported from China-these were a few wild hogs or " razorbacks," which came over in the first shipment. We have never come across one since, as this class of pig has not been exported.

It has been shown that "measled "pork and beef kept for $\mathrm{I}_{4}$ to $2 \mathrm{I}$ days at $-10^{\circ}$ to $-\mathrm{I}^{\circ} \mathrm{C}$. con tain no living parasites.

Trichina in pork have never been found in many hundreds of examinations carried out at Liverpool, both from China, United States, and New Zealand. In the case of trichinosis freezing is less effective. Dr. Kuhn found that trichinous pork could be kept for seven weeks in a frozen state without any fatal effects on the parasite.
Small cysts (echinococcal, etc.) have been found in frozen liver and kidneys from the United States and South America.

Apart from the effect of refrigeration on these various parasitic conditions, it is not desirable that meat infected in this way should be passed for human consumption. The meat is distinctly unsound, and contains in the majority of the cases local inflammatory products which should not be overlooked. In some cases where the disease is localised the organs may be removed, but where the parasites are widespread the carcase must be seized.

Another condition which usually arises before foods are placed in refrigeration is decomposition, although this may arise subsequently, mainly through a breakdown in the refrigerating apparatus or to defective insulation. Under this heading one of the most important is "bone taint." If freshly killed carcases be introduced too soon into a cold atmosphere they are very liable to damage and "bone taint;" it requires a very gradual withdrawal of heat so that no harm may result. Now, "bone taint" occurs in the deeper portions of a hindquarter of beef in and near the bone, and is detected when the meat is bored through with an auger and a decided taint of decomposition is detected. It is caused during the cooling of the carcase where proper means have not been taken to allow the animal heat to escape; and decomposition occurs in the interior: this can in many cases be obviated by hanging the meat in a current of cool air before putting it into the refrigerator.

Quarters of beef from foreign countries have frequently come to Liverpool affected with "bone taint;" it cannot be detected until the quarters are individually tested. At the present time very few of such quarters are found, owing to better cooling methods.

Again, the methods of transportation from slaughter-houses or stores to the ship may be slow and softening or post-mortem changes may be more or less extensive before the meat is put on shipboard, or in making up shipments of rabbits it has happened that putrid rabbits have been packed amongst sound ones. It is unnecessary to further describe instances which may give rise to such conditions.

Under the category of conditions which may arise in the course of refrigeration the most important, and one which we have to deal with very frequently, is the occurrence of moulds 
and sliminess on beef and other food products. These moulds are the greatest cause of anxiety and loss to the refrigeration trade. They may frequently be found on refrigerated meats, poultry, game, and fruits. It is not infrequent to see carcases of mutton, etc., covered with colonies of all kinds of brightly coloured saprophytic moulds and bacteria (blue, green, white, yellow, and pink). The cause of the trouble is some fault in the refrigeration or in the insulation, but may also be started through defective methods of transit.

As is well known, these mould germs are cosmopolitan, and readily develop where moisture, food, and other conditions are suitable. The commonest species comprise Pencillium glaucum (blue-green mould), forming at first a white mycelium, the subsequent blue colouration being due to the result of fructification, Pencillium candidum, Mucor mucedo, and others. One of the chief reasons for the growth of moulds on refrigerated produce is the fact that whilst their optimum temperature for growth is $5^{\circ}$ to $10^{\circ} \mathrm{C}$., they are found to develop at very low temperatures, e.g. $-6^{\circ} \mathrm{C}$., whilst bacteria are rendered dormant. The chief point seems to be that the spore which has settled on the meat requires some moisture before it will begin development; this is afforded by some chance surface condensation of moisture, such as an accidental and temporary rise of temperature in a moist atmosphere. Once this is afforded the mycelium slowly but surely spreads, and it is supposed that this vegetable mycelium, having once got a start, is able to make headway by its own heat on the frozen surface. Later slight decomposition may set in underneath.

The Linley process for the preservation of chilled meats by formalin and subsequently by dry air has mainly this object in view, viz., to keep down excessive humidity.

One of the principal foods affected with moulds is frozen rabbits from Australia. Mr. Tabor, of London, who was the first importer of Australian and New Zealand rabbits, and has had much to do with this trade, has stated that it is his experience that New Zealand rabbits, apart from decomposition, are never found to be affected with mould, because they were packed in solid crates; this doubtless protects the rabbits from sudden changes of temperature during transit from store to ship.

The presence of mould on meat and poultry. is a matter to be very carefully considered by the food inspector as regards its harmfulness to man. If the monld be present in only small amount, for example, in the case of poultry or game, and the underlying tissue shows no evidence of decomposition, then there will be no need to take further action than to allow the removal of the superficial mould, or the excision of the superficially affected portions in beef and mutton, as has been frequently done in Liverpool. Should, however, the coating of the mould have reached a large amount it will be necessary to consider it in connection with changes in the underlying Hesh associated with the presence of bacteria of decomposition.

A short time ago chilled beef from the Argentine was occasionally affected with blackish or olive green spots. These were found to be due to a fungus, which has been shown by Professor Nassée to be a species of Cladosporium; the fungus penetrates the subcutaneous tissue as a dense web of olive green coloured hyphæ. The fungus is non-pathogenic, and the parts of the meat affected are removed.

An interesting example of the growth and effects of moulds occurred on some frozen Chinese bacon which came into Liverpool. On the rind were found a few white colonies of mould, which had caused numerous irregular pits or depressions in the skin, with liquefaction in the same way as liquefying colonies of bacteria would cause liquefaction of gelatine. Dr. MacFadden kindly obtained a report for us from Prof. Massée, who stated that the fungus was Pencillium candidun, a saprophytic mould of harmless nature.

These are the more important facts in regard to refrigeration as it affects the preservation of foods, and this resume will have emphasised that refrigeration affords a ready means of obtaining a plentiful and cheap supply of food; that every means is now being taken to obtain and keep this supply wholesome by the constant attention of the producer abroad to the methods of inspection and handling, and. by its thorough examination on landing in this country.

The subject of food control both in this country and clsewhere has now been broadened; whilst the old methods of detection of diseased food and the analysis for adulteration are still in force, the subject has developed along more important lines of sanitation so that there shall be the necessary supervision of the handling of the food products in preparation, packing, storage, and distribution. 


\section{DISCUSSION.}

The President said that Dr. Hanna's paper was most interesting and full of knowledge, and he was sure that many Fellows would have something to say upon it.

DR. A. W. J. MACFADDEN said that the paper was a most valuable one, and he thought it would enable those members who were not Port Medical Officers to realise in some degree the access in the amount and variety of work which had fallen on Port authorities since the Foreign Meat and Unsound Food Regulations came into force. Of course, in Liverpool a good deal of work of this kind was done before these regulations were issued, but since then, in all our important ports, there had been excellent opportunities for making observations regarding the question of refrigeration and its effect on food. The experience which had been accumulated in various large centres of importation was exceedingly valuable, and well worth recording. Dr. Hanna had mentioned that in regard to chickens the United States people had discussed the question of prolonged cold storage. He had indicated certain disadvantages which arose from the storage of food in freezing temperatures-such as evaporation and the different changes in tissue, apart from bacterial growths. The United States authorities had taken a rather strict view as to the length of time permissible for the cold storage of different food products, and had recently issued regulations limiting the time in the case of certain foods, for example, to four months for beef, two months for fish, and so forth. It was, of course, desirable for the reasons given by Dr. Hanna that indefinite cold storage should not take place, and in a country like America, where such products might be accumulated to a large extent, some limitation was doubtless necessary. In this country, however, where there was not quite the same danger of any prolonged storage owing for one reason to the limited number of cold stores available, the question was probably not of such urgency. Dr. Hanna had given an interesting account of the growth of different moulds on beef, and the effect on refrigeration of these different moulds. That was one of the greatest difficulties that had to be overcome, and one which had undoubtedly exercised the ingenuity of refrigerating engineers. He hoped that before long they would be able to perfect their methods so as to prevent the loss which arose from their source.

Dr. Barnetr said he should like to ask Dr. Hanna what was the orthodox method of defrosting a small portion of beef, not a whole quarter. Should it be kept sufficiently long to lhang it, and if so, did it not waste a bit?

Dr. HanNa said that it ought to hang a day and a half or a couple of days to get the best results from a comparatively small joint. He had had no experience of large joints; but perhaps the beef would decompose to some extent if kept in a warm moist atmosphere. He knew that the flavour and condition were very much improved after being hung for a couple of days.

DR. BARnetT asked if that applied to beef, mutton and lamb, or to beef only?

DR. J. TubB-Thomas stated that according to experiments he had made, chilled meat was quite satisfactory if put in the oven to cook without defrosting.

DR. R. Dudfield (Paddington) said he was afraid he could not endorse the statement of the last speaker on the cooking of chilled meat. His own experience was that it was necessary in the winter time to keep the joint in the kitchen over-night, the warmth of the kitchen being found to defrost the meat sufficiently to secure perfect cooking next morning. He was sorry Dr. Hanna had not said more as to the use of refrigeration in food-stuffs other than those imported. For instance-cream was an article which he thought should be preserved by refrigeration and not by chemicals. He could not help thinking the time had come. when they ought to do their best to stop the use of chemical preservatives for cream and butter. He could not see why in this country they should not adopt the system followed in the United States, where the only preservatives allowed to be used in foods were cold and salt.

A Member asked Dr. Hanna if he had any experience as to what was the result of continuous freezing and thawing. In the poorer districts of N.E. Lancashire it was quite a common practice for the meat to be thawed and frozen again at continuous periods. Had that practice any effect on the meat after being cooked? He had also known of fish being thawed and frozen time after time for a month.

Dr. Barnett said he had not put his question very clearly. Was there any method by which an ordinary householder could defrost the meat sufficiently gradually to preserve the flavour? His own opinion was that it was best to hang it for a fortnight.

Dr. G. T. Cattell said he would like to ask if there was any difference in the flavour of meat or other articles which had been frozen when defrosted and cooked? Personally he did not think there was any; but they were always meeting with people who said "I can always tell frozen mutton or beef directly I taste it." His belief was that that was nonsense. In his own experience he had set before one of these sort of people a joint of New Zealand lamb, when his friend said after partaking of it: "This is most excellent Welsh mutton, and I have never eaten anything better." It was the same with poultry and game. In the first day of the season they often got grouse, partridges and pheasants which, as a matter of 
fact, had been kept in cold storage all the year, and when taken out of the refrigerators their taste was very good. He had eaten soles which had been kept in the refrigerators for six or nine months. What was Dr. Hanna's experience; did the flavour of these articles of food change after prolonged refrigeration?

Dr. HaNNa, replying on the discussion, said that the question of taste and flavour of defrosted meat was a most difficult problem. There was no doubt that chilled meat approached most nearly to fresh conditions. One thing was found, that it was as tender as fresh meat, and so also was frozen meat as tender owing to the maturation and the breaking up of the fibres. The fla vour depended mainly on the length of time it had been frozen, and on how the meat was defrosted; when properly defrosted and compared with a lot of our own home-grown fresh meat it is equally as good. As he had said, he thought the best period for defrosting was from one and a half to two days. There was one point worth noting about frozen mutton. If a leg of mutton was defrosted by suspending it by the shank, the fluids and natural salts were allowed to drip away, but if it were suspended with the shank lowermost, the natural salts and fluids percolated all through the joint and were preserved. He thought that some endeavour should be made to preserve cream and milk by means of refrigeration. Although bacteria would grow even at low temperatures, still their activities were much reduced by the operation of these low temperatures. Repeated freezing and thawing, especially of fish, was bad, as any fishmonger of experience would tell them. $\mathrm{He}$ could not say what the effect of frequent freezing and thawing would be on meat, but he should imagine that it would gradually break up the fibres and tissues, and that when finally put on sale the juices would escape much more readily. A reference had been made to the manner in which chickens had been dealt with by the American authorities. It was found from experiments that the chickens became shrivelled as the period of refrigeration was prolonged, and that after a year they had much deteriorated as a food product. Dr. MacFadden had referred to the indefinite time which foods could be retained in cold storage in this country. That was a matter which ought to receive consideration here, because cold storage might lead to the cornering of food products by various trusts; and it was very desir. able that the cornering of food should not be allowed in these islands. In fact it had been mentioned to him that if milk and cream refrigeration were generally introduced, the milk supply of the people would be cornered until the prices were raised against poor people. Very considerable experiments would be required to eliminate the growth of moulds on refrigerated foods. He him- self did not approve of the formalin method; the main point to be studied was the hurnidity of the air, and if the holds of the ships bringing the meat were kept at a right point of humidity and temperature moulds would gradually disappear in the cargoes.

The President said he must express the pleasure with which he had heard Dr. Hanna enter into a good deal of detail on this question of refrigeration. Rightly or wrongly, one got the impression that in the future they must look even more extensively than at present for preserved foods. It was refreshing to find that Dr. Hanna took full advantage of the opportunities which Liverpool afforded for studying this question. There was an enormous amount of information still required, not only in regard to the chemical changes produced in food constituents, but in regard to the possibility of alterations of food values. He was delighted to hear Dr. Dudfield express himselt as he had done as to the desirability of getting rid of anything chemical in regard to milk preservation. The other phase of cold was heat, and it seemed to him that in the near future they would be compelled to decide, on definite scientific inquiry, whether the application of excessive heat was not more injurious than the application of excessive cold as a preservative.

The PResident proposed a vote of thanks to Dr. Hanna for his valuable paper.

Dairies, Cowsheds and Milkshops Order. Proceedings under Regulations.

A FINE of $\ell_{3}$ and costs was imposed by the Cardiff Stipendiary, on 31st December, I913, upon Wm. Lisk, who was summoned at the instance of the Inspector of Nuisances on the ground "That he, William Lisk, of 17 , Penypeel Road, Cardiff, on the 5 th day of December, 19 13, at the City aforesaid, being a purveyor of milk did, without lawful authority or excuse, suffer a certain cow belonging to him to be milked for the purpose of obtaining milk for sale, without the udder and teats of such cow being thoroughly clean at the time of milking, and without the hands of the person milking such cow also being thoroughly clean and free from all infection and contamination, contrary to the Regulations made under the Dairies, Cowslieds and Milkshops Order, I 885."

For the prosecution it was stated that defendant kept nine cows, and on the 5 th December the cowshed, situated on Ely Moors, Cardiff, was visited by Mr. P. J. Mullane, Veterinary Inspector to the Corporation, who found that the hindquarters of the cows were dirty and that manure was caked on the skin of the cows. One cow at the time of milking had a dirty udder and teats, and the hands of the person milking the cow were very dirty and stained with manure. For the defence it was said that defendant gave orders for the animals to be kept clean. He had also told the milker to keep his hands clean. 